\title{
Erosion of undisturbed clay samples from the banks of the St Lawrence River
}

S. J. GASKIN: Civil Engineering and Applied Mechanics, McGill University, 817

Sherbrooke St. W., Montréal, Québec, Canada, H3A 2K6.

J. PIETERSE ${ }^{1}$ : Civil Engineering and Applied Mechanics, McGill University, 817

Sherbrooke St. W., Montréal, Québec, Canada, H3A 2K6.

A. ALSHAFIE ${ }^{2}$ : Civil Engineering and Applied Mechanics, McGill University, 817

Sherbrooke St. W., Montréal, Québec, Canada, H3A 2K6.

S. LEPAGE $^{3}$ : Centre St. Laurent, Environnement Canada, 105, rue McGill, 8ième étage, Montréal, Québec, Canada, H2Y 2E7.

Corresponding author:

S. J. GASKIN: Civil Engineering and Applied Mechanics, McGill University, 817

Sherbrooke St. W., Montréal, Québec, Canada, H3A 2K6.

Tel: 514-398-6865

Fax: 514-398-7361

susan.gaskin@mcgill.ca

Word count: 6073 words +3 tables +11 figures.

\footnotetext{
${ }^{1}$ Akazienweg 8, 64521 Gross-Gerau, Germany.

${ }^{2}$ Building, Civil and Environmental Engineering, Concordia University, 1455 de Maisoneuve Blvd, W., BE-341, Montréal, Québec, Canada, H3G 1M8

${ }^{3}$ La Biosphère, Environnement Canada, 160, Chemin Tour de l'Isle, Ile Ste-Hélène,Montreal, Quebec, Canada, H3C 4G8.
} 
Gaskin, S.J., Pieterse, J. AlShafie, A. \& Lepage, S. (2003) Erosion of undisturbed clay samples from the banks of the St. Lawrence River, Canadian Journal of Civil Engineering, 30: 585-595. doi: 10.1139/L03-008

Abstract: In some regions the clay banks of the St. Lawrence River along the Montreal to Lac

St. Pierre reach have recession rates of up to 1 to $3 \mathrm{~m}$ per year. The banks are formed of structured marine clays of the Champlain Sea (Leda clay). In this laboratory study, undisturbed samples of this inorganic clay of high plasticity, taken at Iles de Verchères, were subjected to a unidirectional current and a constant wave climate to investigate the mechanisms of erosion and the factors influencing erosion rates. Initially surface erosion resulted in the formation and enlargement of cracks, and the smoothing of competent surfaces. The dominant erosion process was a mass erosion of the blocks of clay delineated by the cracks. Desiccation or weathering significantly increased erosion rates, as tension cracks formed due to drying and, upon rewetting, the formation of micro-fissures resulted in disintegration into small easily erodible flakes. The estimated critical shear stress of the samples was 6-20 Pa. For the St. Lawrence River, these results suggest that waves are the dominant erosion mechanism, with shipping contributing significantly to the erosion of banks close to the navigation channel. Weathering caused by wetting and drying from changing water levels or wave run-up greatly increases erosion rates.

Key words: Erosion, Leda clay, undisturbed clay, natural clay structure, St. Lawrence River, waves, weathering, desiccation, vegetation. 
Gaskin, S.J., Pieterse, J. AlShafie, A. \& Lepage, S. (2003) Erosion of undisturbed clay samples from the banks of the St. Lawrence River, Canadian Journal of Civil Engineering, 30: 585-595. doi: 10.1139/L03-008

\section{Introduction}

In some regions the clay banks of the St. Lawrence River along the Montreal to Quebec City reach have recession rates generally of up to 1 to 3 m/yr (Panasuk 1987, D’Agnolo 1978, Argus Groupe-conseil 1991). Between 1964 and 1983, a period for which the water levels in the St. Lawrence River were higher than those observed in recent years, rates up to $6 \mathrm{~m} / \mathrm{yr}$ were observed (Dauphin, 2000). $440 \mathrm{~km}$ of shoreline suffer erosion to a certain extent between Cornwall and Montmagny (Lehoux 1996; Dauphin 2000). The most active reach is from Montreal to Sorel, where $80 \%$ of the banks are within $800 \mathrm{~m}$ of the navigable channel (Lepage $e t$ al. 2001). The suspended sediment budget between Cornwall and Quebec City shows that shore erosion contributes between 30 to $65 \%$ of all the suspended sediment (or 1.7 to $4.5 \times 10^{6}$ tons/yr) that is exported to the St. Lawrence estuary at Quebec City (Rondeau et al. 2000; Dauphin 2000).

This laboratory study investigated the mechanisms of erosion and the factors influencing erosion rates for undisturbed samples of the Champlain Sea clay which forms the banks of the St. Lawrence River. Samples were collected from the Iles de Verchères in the Montreal to Contrecœur reach of the St. Lawrence River where increased erosion rates have been found (Figure 1). This work is a sub-project of a larger study which aims to develop a 2-D hydrodynamic model of sediment transport, including that due to bank erosion, in the St. Lawrence River (Lepage et al. 2001; Lepage and Richard 2001).

The erosion of cohesive sediments or clays is very complex and is a function of sediment composition, microscopic and macroscopic clay properties, clay fabric, pore and eroding fluid 
Gaskin, S.J., Pieterse, J. AlShafie, A. \& Lepage, S. (2003) Erosion of undisturbed clay samples from the banks of the St.

Lawrence River, Canadian Journal of Civil Engineering, 30: 585-595. doi: 10.1139/L03-008

composition, consolidation pressure, $\mathrm{pH}$, thixotropy and temperature. The amount and rate of erosion also depend on the eroding agent - waves, current, rainfall, runoff, weather and water levels. Studies have shown that erosion of undisturbed samples of clay occurs predominately at fissures and planes of weakness by removal of blocks and flakes of clay. Champlain Sea clay contains many fissures and planes of weakness and is likely to erode in this manner. It is therefore important to test undisturbed samples to take account of the effect of the natural clay structure on its erosion characteristics.

\section{Literature Review}

Erosion of cohesive sediments on banks and shorelines can occur due to currents and wave action exerting a shear stress on the sediment. When the shear stress exceeds the shear strength, erosion occurs. Waves breaking on a sediment surface can exert shear stresses larger than those exerted by most river currents, and the breaking of the waves causes oscillating shear strains in the sediment (Vallejo 1980; Maa \& Mehta 1987). Wave erosion of cohesive sediments occurs at the zone of dominant wave breaking, with changes in water levels shifting this zone (Bishop et al. 1992). This results in the recession of a cohesive bluff being controlled by the downcutting of the nearshore profile (Kamphuis 1987). As the bluff recesses the foreshore erodes to maintain its slope. Breaking and plunging breakers are much more erosive than spilling breakers (Skafel 1995). Studies on the erosion of the clay banks of the St. Lawrence River in the Montreal to Quebec City reach have identified ship's wakes and wind waves as the main eroding agents, with ice effects, currents and water level fluctuations also contributing (D’Agnolo 1978; Ouellet \& Baird 1978; Panasuk 1987; Dauphin 2000). 
Gaskin, S.J., Pieterse, J. AlShafie, A. \& Lepage, S. (2003) Erosion of undisturbed clay samples from the banks of the St. Lawrence River, Canadian Journal of Civil Engineering, 30: 585-595. doi: 10.1139/L03-008

Shear stress over cohesive sediment beds results in several modes of erosion, which can be roughly classified as surface erosion, mass erosion and entrainment of fluid mud in the order of decreasing shear stress. Surface erosion occurs when flocs or particles are entrained due to hydrodynamic lift and drag forces, which break up inter-particle bonds. For clays, surface erosion is seen as smoothing or pitting of the surface and also occurs at discontinuities (Krone 1999). Mass erosion occurs when the sediment fails at an embedded plane and a block of sediment is removed or brought into suspension shortly thereafter. The structure of the sediment and strength of the planes of weakness determine sediment breakup (Lefebvre et al. 1985). Entrainment of fluid mud is due to flow induced destabilization resulting in entrainment and mixing of the fluid mud with the overlying flow. This usually occurs only for freshly deposited samples with a very high moisture content, typically found in estuaries (Mehta 1991). Increased erosion and erosion rates occur when sand is present in the eroding fluid due to sand blasting or milling of the cohesive sediment (Kamphuis 1983; Kamphuis et al. 1990). In this case critical shear stresses are in the range of the critical shear stress of the sand.

For remoulded clays, bulk geotechnical properties can be used to predict erosion rates. The critical shear stress of the sediment varies with its shear strength, consolidation pressure or plasticity index (Ariathurai \& Arulanandan 1978; Kamphuis 1983). However, erosion of undisturbed samples cannot be predicted by bulk soil properties (Partheniades 1965; Lefebvre et al. 1986; Kamphuis et al.1990; Samad et al.1995) because it is the local properties that control erosion (Zreik et al. 1998). 
Gaskin, S.J., Pieterse, J. AlShafie, A. \& Lepage, S. (2003) Erosion of undisturbed clay samples from the banks of the St. Lawrence River, Canadian Journal of Civil Engineering, 30: 585-595. doi: 10.1139/L03-008

The few studies on undisturbed samples have been performed in flumes (Rohan et al. 1980, Kamphuis et al. 1990), in a modified rotating cylinder apparatus (Chapuis 1986), by a drill hole method (Lefebvre et al. 1985, 1986) and in a wave tank (Skafel \& Bishop 1994). Table 1 summarizes the results of these tests, which give critical shear stress values ranging from 0 to over $450 \mathrm{~Pa}$ depending on the source of the clay and hence its varying natural structure and defects. Erosion of these samples began at zones of weakness such as cracks, fissures, silty pockets and planes of weakness, and proceeded by a mass erosion process, in which blocks or flakes of sediment were removed (Lefebvre \& Rohan 1986; Kamphuis et al. 1990; Skafel \& Bishop 1994). These tests confirm, that when undisturbed and unweathered, these clays are very resistant to erosion (Rohan et al. 1980; Lefebvre et al. 1985; Lefebvre 1986; Skafel \& Bishop 1994) and that when weathered, having more fissures, they can have very high erosion rates (Lefebvre et al. 1985).

The in situ moisture content affects the clay structure and is an important factor influencing runoff erosion resistance of clayey soils. Rapid wetting of soils with low initial moisture contents causes slaking, where entrapped air forces its way out breaking apart the aggregate. The water brought in during rapid wetting causes differential swelling resulting in microfissuration or the creation of planes of weakness (Panabokke \& Quirk 1957; Le Bissonais et al. 1989; Truman et al. 1990; Govers \& Loch 1993). The breakup of the cohesive sediment, and correspondingly the susceptibility to erosion, increases with lower initial moisture content, increased rate of wetting and successive wet-dry cycles. This is relevant to cohesive river banks, as shown by the greatly increased erosion rates of dried samples of undisturbed cohesive sediment, which can be considered equivalent to weathered river banks (Lefebvre et al. 1985). 
Gaskin, S.J., Pieterse, J. AlShafie, A. \& Lepage, S. (2003) Erosion of undisturbed clay samples from the banks of the St.

Lawrence River, Canadian Journal of Civil Engineering, 30: 585-595. doi: 10.1139/L03-008

Rates of erosion of cohesive river banks thus depend on the combination of the temporal variations of in situ bank moisture content and the magnitude and duration of wave or current action (Hooke 1979; Lawler 1992).

The effects of vegetation on the rate of erosion of cohesive sediments are complex and, while most effects increase erosion resistance, others decrease it. The canopy of the plant protects the ground from rain, wind and frost, and if submerged it decreases the erosive forces by decreasing the flow velocity due to the current or waves at the soil surface. The root system strengthens the soil by transferring the shear stress in the soil to tensile stress in roots via the skin friction of the root (Coops et al. 1996; Thorne 1990). However, decayed dead roots will leave voids and holes, reducing cohesion and allowing ingress of water that can result in freeze-thaw damage (Thorne 1990). Desiccation of the soil from trees and other vegetation can occur, particularly during droughts. There are several more subtle effects and their interaction and combined effects are not completely understood.

\section{Experimental Study}

This study was undertaken to determine the importance of factors influencing the rates and mechanisms of erosion of the Champlain Sea clay banks of the St. Lawrence River between Montreal and Contrecœur. Laboratory erosion tests were performed on undisturbed samples to model field behaviour as closely as possible.

Two sets of erosion tests were performed. In the first set, samples were subjected to a unidirectional current and the effect of flow velocity, presence of plant root matrix, and moisture 
Gaskin, S.J., Pieterse, J. AlShafie, A. \& Lepage, S. (2003) Erosion of undisturbed clay samples from the banks of the St.

Lawrence River, Canadian Journal of Civil Engineering, 30: 585-595. doi: 10.1139/L03-008

content was measured. In the second set, samples were subjected to a constant wave climate and the effect of bank slope, presence of plant root matrix, and moisture content was measured.

\section{Collection of Undisturbed Riverbank Samples}

To relate the results of this study directly to the phenomena occurring in the St Lawrence River, undisturbed samples from the study reach were used in order to have representative material properties such as structure, moisture content, composition and vegetation levels. Fifteen samples were collected from the south shore of Iles de Verchères and two from the south shore of the St. Lawrence River just upstream of Contrecœur. This was to check that the clay deposit was similar on both sides of the channel. Samples were collected at low water levels and all samples were taken just above the water level on the gently sloping foreshore (slope of 0.02 to 0.07) below the steep backshore bluff in the strata of gray and compact clay, which is overlain by a thin layer of sand (Figure 2). The water level of the St. Lawrence River was fluctuating during the sampling period (May - June, 2000) due to precipitation events and temperature changes modifying runoff rates and hence the river discharge. As the samples were taken during low water level periods, they did not have significant surface weathering. Vegetation on the banks is found primarily on the backshore bluff, however as the summer progresses and the water level decreases, seasonal vegetation is also found on the gently sloping foreshore.

The following sampling method was developed to minimize disturbance to the sample (Figure 3). A metal frame ( $0.4 \mathrm{~m} \times 0.6 \mathrm{~m} \times 0.15 \mathrm{~m}$ deep) was carefully pushed into the clay and the clay around the frame removed. A metal cutting sheet cut the sample from the underlying clay. The winch attached to the sheet ensured that the sheet could be pulled slowly and evenly through the 
Gaskin, S.J., Pieterse, J. AlShafie, A. \& Lepage, S. (2003) Erosion of undisturbed clay samples from the banks of the St.

Lawrence River, Canadian Journal of Civil Engineering, 30: 585-595. doi: 10.1139/L03-008

clay to avoid major disturbances to the sample. The sample was transferred to a plywood sheet, wrapped in plastic, sealed with paraffin wax and stored in a humid room until testing. Prior to testing, the sides of the samples were trimmed using a wire cutter to $0.30 \mathrm{~m} \times 0.45 \mathrm{~m}$, but the top (testing) surface was left untouched. Standard soil testing procedures were used to determine the properties of the clay.

\section{Flume Studies}

The erosion at the bed of a channel having a unidirectional current was investigated. The test flume used was a tilting flume with a width of $0.30 \mathrm{~m}$, depth of $0.45 \mathrm{~m}$, length of $9 \mathrm{~m}$, a slope of up to 0.04 and a maximum flow rate of 100 1/s (Figure 4). A false floor was installed in the flume and the sample was placed in a recessed box. The box was fitted with a lifting mechanism so that the top of the sample could be adjusted to be flush with the false floor of the flume. Once the sample was placed in the flume it was subjected to a constant flow velocity and its erosion observed, its surface profile measured and its appearance recorded with a camera. Once erosion at a given velocity had decreased to a negligible rate, the flow velocity was incrementally increased and the procedure repeated. This continued until the maximum flow velocity of the flume was reached. Starting with the third sample, the samples were pre-soaked for 72 hrs to allow for swelling of the sample. This allowed erosion rates to be estimated, as volume changes were due only to erosion rather than the combined effect of swelling and erosion. The limitation of using an open channel flume for the experiments was the low range of possible flow velocities. 
Gaskin, S.J., Pieterse, J. AlShafie, A. \& Lepage, S. (2003) Erosion of undisturbed clay samples from the banks of the St. Lawrence River, Canadian Journal of Civil Engineering, 30: 585-595. doi: 10.1139/L03-008

\section{Wave Tank Studies}

The erosion due to breaking waves at the shore was investigated. The wave tank used was of the paddle wave generation type (Figure 5). The tank was $4 \mathrm{~m}$ long $\mathrm{x} 0.30 \mathrm{~m}$ wide $\mathrm{x} 0.50 \mathrm{~m}$ deep. The sample was recessed into the bank so that the surface was flush with the bank slope of either $0.18\left(10^{\circ}\right)$ or $0.36\left(20^{\circ}\right)$. The mean water level was at the midpoint elevation of the sample and corresponded to a water depth of $0.25 \mathrm{~m}$. The paddle-generated waves had an average wave height of $0.06 \mathrm{~m}$, average wave period of $0.8 \mathrm{~s}$ and a wavelength of $1.0 \mathrm{~m}$. The waves are classified as transitional waves (with depth/wavelength $=0.25$, USACE 1984), which were observed in the tests to be surging waves for the $10^{\circ}$ slope and surging-plunging waves for the $20^{\circ}$ slope. This wave climate could result from wind action at the field site. For each experiment, the sample was subjected to the waves for a period of time, after which measurements were taken to determine the volume of eroded material and the sample was photographed. This continued until either the sample was completely eroded or 7 days had elapsed.

\section{Results}

The cohesive sediment samples from the two locations in the study reach were very similar indicating the deposit is not a localized deposit. They were a Champlain Sea clay, which is a pseudo-consolidated post-glacial sediment deposited in brackish water at the end of the last ice age on the bed of a major inland arm of the ocean called the Champlain Sea (these clays are also known as Leda clays). This is a cemented clay, in which the particles were deposited with edge to face contact rather than the face to face contact of particles deposited in fresh water (Sangrey 1972). The soil is classified as an inorganic clay of high plasticity $(\mathrm{CH})$, with $75 \%$ clay sizes, 
Gaskin, S.J., Pieterse, J. AlShafie, A. \& Lepage, S. (2003) Erosion of undisturbed clay samples from the banks of the St.

Lawrence River, Canadian Journal of Civil Engineering, 30: 585-595. doi: 10.1139/L03-008

$15 \%$ fine silt and $10 \%$ greater than fine silt sizes. The moisture content was $57 \% \pm 3$, the liquid limit $72 \% \pm 3$ and the plastic limit $20 \% \pm 1.5$, giving a plasticity index of $52 \% \pm 4$. A high degree of homogeneity was found between the samples collected. The composition of the sediment was 35 to $60 \%$ phyllosilicates, 25 to $50 \%$ quartz, feldspar and amphibole and 5 to $15 \%$ dolomite and calcite (Lepage et al. 2001). (Note these cemented clays are a unique type of clay having a different behaviour to that of non-cemented clays. They have water contents above the liquid limit, have low strain rates up to the yield point where the cementation bonds rupture, and have large strain rates and the possibility of liquifaction beyond the yield point (Sangrey 1072).)

\section{$\underline{\text { Erosion Due to a Unidirectional Current }}$}

Six samples were subjected to an incrementally increasing unidirectional current, whose velocities fell in the range of $\sim 0.2$ to $1.8 \mathrm{~m} / \mathrm{s}$. A summary of the tests is given in Table 2 , detailing the sample characteristics, velocity range, erosion period, critical velocity and estimated critical shear stress. Mass erosion was the dominant erosion process and the 1 to $30 \mathrm{~mm}$ range in size of the eroded blocks was dependent on the natural structure and fissuration of the sample.

For the samples at their natural moisture content subjected to a unidirectional current, the erosion was minimal until the velocities reached 0.5 to $1 \mathrm{~m} / \mathrm{s}$. Once erosion had begun at a particular velocity, the rate of erosion was initially rapid then decreased with time, becoming zero at some point. On some of the dense uncracked or competent surface areas of the sample no significant surface erosion was seen, but the surface became polished with time. On other competent surfaces some pitting was seen. As the erosion progressed cracks and fissures became visible. These enlarged with time due to preferential surface erosion along the planes of weakness due to 
Gaskin, S.J., Pieterse, J. AlShafie, A. \& Lepage, S. (2003) Erosion of undisturbed clay samples from the banks of the St.

Lawrence River, Canadian Journal of Civil Engineering, 30: 585-595. doi: 10.1139/L03-008

the natural clay structure. The surface erosion was also indicated by the cloudiness of the water due to the suspension of the eroded clay particles. The enlarged cracks delineated blocks of clay, which were then eroded in a mass erosion process (Figure 6a). The presence of roots in the sample had two opposing effects. First the presence of the roots resulted in a greater number of cracks and fissures in the clay making it more susceptible to erosion. However, once a block of clay became isolated by the cracks, the roots slowed down its removal from the sample. The volume of clay eroded over the erosion period of 12 to $70 \mathrm{hrs}$ for the samples at their natural moisture content was visually estimated to be 0.5 to 2 liters, i.e. of the same order of magnitude as for the wave tests. Most of the eroded volume was due to the mass erosion of the blocks.

Submitting the sample to drying before the tests, which is equivalent to weathering, resulted in dramatically increased erosion. The effect of drying was to increase the number of tension cracks and fissures. In addition, upon re-wetting of the sample, when it was exposed to the flow, the very rapid water uptake resulted in differential expansion and formation of micro-fissures. The erosion of the resulting 0.5 to $2 \mathrm{~mm}$ flakes of clay was very rapid, with the whole sample disintegrating and eroding in less than half an hour.

The critical velocity of the samples was defined as the point at which the erosion rate increased dramatically, this was determined visually. An estimation of the critical shear stress was calculated by assuming Keulegan's logarithmic velocity profile for rough turbulent flow (shear Reynolds number, $U^{*} k_{s} / v$, greater than 70) to calculate the shear velocity.

$$
\frac{u}{U^{*}}=\frac{1}{\mathrm{~K}} \ln \left(\frac{z}{k_{s}}\right)+8.5
$$


Gaskin, S.J., Pieterse, J. AlShafie, A. \& Lepage, S. (2003) Erosion of undisturbed clay samples from the banks of the St.

Lawrence River, Canadian Journal of Civil Engineering, 30: 585-595. doi: 10.1139/L03-008

where $u$ is the velocity at depth $z$, $U^{*}$ is the bed shear velocity, $K$ is von Karman's constant, $k_{s}$ is

the height of the roughness and $v$ is the kinematic viscosity of water. As surface velocities were measured, $u$ is the surface velocity and $z$ is the flow depth. The roughness height of the eroding sample was estimated to be 1 to $3 \mathrm{~cm}$, which was the surface roughness due to the erosion of clay blocks. Critical bed shear stress, $\tau_{c r}$, was then calculated.

$$
\tau_{c r}=\rho U^{* 2}
$$

where $\rho$ is the density of the water. This resulted in estimated critical shear stresses of 6 to $20 \mathrm{~Pa}$ for the undisturbed samples at their natural moisture content and much lower values for the desiccated samples. This is in the range of all previous results, given in Table 1, except for those of Lefebvre et al. (1985, 1986), which will be discussed further below.

\section{Erosion Due to a Constant Wave Climate}

Ten samples were subjected to a constant wave climate for up to 336 hours or until the complete sample had eroded. A summary of the tests is given in Table 3, detailing the sample characteristics, erosion period, eroded volume, rate of erosion and average size of largest block eroded. Note that the applied shear stress cannot be determined under breaking waves. However, the observed erosion rates allowed for a relative comparison of susceptibility to erosion.

At the start of the tests, the waves initially removed the sand layer lying on the sample's surface. As erosion progressed some surface erosion occurred as indicated by the cloudiness of the water due to suspension of the clay particles. The surface erosion was visible as a smoothing of competent surfaces and in the development of cracks. Under the breaking waves, the additional 
Gaskin, S.J., Pieterse, J. AlShafie, A. \& Lepage, S. (2003) Erosion of undisturbed clay samples from the banks of the St. Lawrence River, Canadian Journal of Civil Engineering, 30: 585-595. doi: 10.1139/L03-008

turbulence at the discontinuities and the oscillating pressures and shear stresses resulted in enlargement of cracks and fissures. This crack system, which is a function of the natural structure of the clay, began to delineate blocks (Figure 6b). These were then removed in a mass erosion process due to the combined action of the lift and drag forces due to the turbulent flow velocities and to the oscillating pressures in the breaking waves. The erosion occurred predominantly at the point where the plunging breakers were crashing onto the sample for the samples without roots, but for the samples with roots the erosion was more even over the sample.

Erosion of the samples at their natural moisture content occurred predominantly due to mass erosion, as blocks of clay delimited by the cracks, with a size range of $<1 \mathrm{~mm}$ to $\sim 50 \mathrm{~mm}$ for their longest axis, were removed. The effect of an increased bank slope, from 0.18 to 0.36 , was a doubling of erosion rates and an increase by approximately $20 \%$ in the maximum size of the eroded particles (Figure $7 \mathrm{a}$ for the 0.18 slope and Figure $7 \mathrm{~b}$ for the 0.36 slope). The effect of the root matrix in the sample was complex, both increasing the number of cracks and slowing the removal rate of loosened blocks. These tests indicated that the net result was a reduced erosion, with the effect lessened for the pre-soaked sample and not discernable for the dried sample. The presence of the root matrix also resulted in an increase in the swelling of the sample during presoaking as the roots allowed greater penetration of the water. Pre-soaking the sample increased the moisture content of the surface, hence softening it, and resulted in a small increase in erosion rates. The effect of reducing the initial moisture content of the sample by drying (equivalent to weathering), samples 7 to 10 , resulted in dramatically increased erosion of the desiccated material. The drying increased the number and extent of the tension cracks and, upon re-wetting of the sample by the waves, differential expansion of the clay resulted in the formation of micro- 
Gaskin, S.J., Pieterse, J. AlShafie, A. \& Lepage, S. (2003) Erosion of undisturbed clay samples from the banks of the St. Lawrence River, Canadian Journal of Civil Engineering, 30: 585-595. doi: 10.1139/L03-008

fissures. The sample disintegrated into 0.5 to $2 \mathrm{~mm}$ flakes that eroded very rapidly, resulting in complete erosion of the sample in less than 2 hours (Figure 8).

\section{Summary}

The process of erosion of the clay was, in general, quite similar for all tests on samples at their natural moisture content (i.e. non-desiccated), both that due to a current and that due to waves. Some of the samples had a thin layer of sand lying on the surface; these particles were quickly removed as soon as the flow or the waves were started. Erosion then proceeded as small cracks and fissures appeared and were enlarged in a process of surface erosion. Surface erosion, visible as polishing, also occurred to a small amount on the surfaces surrounded by the cracks. As the cracks enlarged they began to isolate and loosen blocks of clay. These blocks were then eroded in a mass erosion process as they were removed once the flow or wave turbulence was large enough. Figure 6 shows typical samples during the erosion process.

The desiccated samples showed greatly increased erosion both due to a current and due to waves. Drying increased the number of tension cracks and, with re-wetting of the samples, the formation of micro-fissures resulted in the sample disintegrating into 0.5 to $2 \mathrm{~mm}$ flakes. The samples were then very susceptible to erosion and completely eroded in under 2 hours.

\section{Discussion}

Mass erosion was the dominant type of erosion due to the presence or development of cracks and fissures in the clay, which are a function of the natural sediment structure and of weathering. Therefore the most important factors in causing the high erosion rate of the clay banks of the 
Gaskin, S.J., Pieterse, J. AlShafie, A. \& Lepage, S. (2003) Erosion of undisturbed clay samples from the banks of the St. Lawrence River, Canadian Journal of Civil Engineering, 30: 585-595. doi: 10.1139/L03-008

Montreal to Contrecœur reach of the St. Lawrence River are the natural structure of the clay and the degree of weathering of the clay. Figure 9 shows the natural structure of the clay in the banks of the St. Lawrence becoming apparent due to weathering. The clay "stones" on the shoreline are evidence of the mass erosion process occurring.

The estimated critical shear stress in this study for the undisturbed samples at their natural moisture content ranged from 6 to $20 \mathrm{~Pa}$. This is within the range of the results in the literature except for the results of Lefebvre et al. $(1985,1986)$. Lefebvre reported critical shear stresses from 100 to $470 \mathrm{~Pa}$ for the Champlain and Tyrell Sea clays. These clays are cemented and, hence, have very strong inter-particle bonds and high resistance to surface erosion. The samples were collected at depth, hence were unweathered and would have had few or no fissures. In addition, in the drill hole test a $6.35 \mathrm{~mm}$ diameter hole is drilled in the sample, and it is this area which is exposed to the flow. The low surface area exposed reduces the possibility of blocks being removed, which is the main erosion mechanism found for the cemented Champlain Sea clay of the present study. Therefore any erosion observed in the drill hole study is due to surface erosion, which requires a higher applied shear stress. The other studies on undisturbed clays at their natural moisture content, that have reported similar critical shear stresses, have also reported erosion processes similar to those of the present study, i.e. dominated by mass erosion, with the natural structure determining the failure planes. The extremely low resistance to erosion of the desiccated samples was also reported by Rohan et al. (1980). 
Gaskin, S.J., Pieterse, J. AlShafie, A. \& Lepage, S. (2003) Erosion of undisturbed clay samples from the banks of the St. Lawrence River, Canadian Journal of Civil Engineering, 30: 585-595. doi: 10.1139/L03-008

In the unidirectional current tests, the critical velocity was in the order of $1 \mathrm{~m} / \mathrm{s}$. A unidirectional current will not cause much erosion of unweathered clay along the banks of the St. Lawrence, because currents of $>0.3 \mathrm{~m} / \mathrm{s}$ are not found along the banks in this reach.

Wave erosion is therefore the dominant agent of erosion and is focused in the breaking zone at the shoreline. Breaking waves result in very turbulent flows with high local velocities, high impact forces in the breaking waves and varying pressure forces in the cracks caused by the wave action. Increased bank slopes result in increased erosion due to the higher erosive forces of the more abruptly plunging waves and due to the lower resistive force of the clay blocks on the steeper slopes. Waves of any type will result in erosion with more erosion occurring the longer the duration of the wave attack or the larger the magnitude of the waves. The impact of the longer duration waves would tend to suggest that wind generated waves are more important than ship generated waves when the banks are exposed to long fetches. However, in the study area, where the effective fetch is less than $3 \mathrm{~km}$ and the shore is close to the shipping channel, ship wakes play a dominant role in the erosion processes.

A study by Ouellet \& Baird (1978) suggested that an evaluation of the energy contained in a wave train could be used to assess the relative importance of wind waves and shipping waves on erosion rates. More recently Dauphin (2000) used this method to estimate that between 50\% and $60 \%$ of the bank erosion is due to commercial shipping, when the distance separating the shore and the shipping channel is less than $400 \mathrm{~m}$. Oscillatory currents of the order of $1 \mathrm{~m} / \mathrm{s}$ occur at the shoreline under the breaking long period surges resulting from the drawdown that accompanies the passage of a ship. At the sampling site, surge periods of 1-2 minutes and water 
Gaskin, S.J., Pieterse, J. AlShafie, A. \& Lepage, S. (2003) Erosion of undisturbed clay samples from the banks of the St. Lawrence River, Canadian Journal of Civil Engineering, 30: 585-595. doi: 10.1139/L03-008

level oscillations of $0.5-1.0 \mathrm{~m}$, that continued for 10 to 20 cycles with decreasing magnitude were observed (Panasuk 1987; Lepage et al. 2001). More than 10,000 vessels a year use the shipping channel and the change in water level caused by their passage is $\sim 70 \%$ of the mean annual water level fluctuation. Shipping is then an import erosive agent due both to the magnitude of the waves and accompanying large local velocities, and due to their contribution to the wetting and drying, hence weathering of the banks, and thus their increased erodability.

Any desiccation of the bank followed by a rapid wetting, or weathering, will result in significant erosion. Figure 9 shows a typical bank showing the effect of desiccation or weathering. Desiccation will occur any time that the bank is exposed to dry air, either due to low water levels, loss of protective vegetation or a period of time without precipitation. The loss of moisture causes a shrinking of the clay and the formation of tension cracks. This results in a macroscopic clay structure of blocks of material separated by cracks with little cohesion between adjacent blocks. The formation of micro-fissures and disintegration of the structure of the clay blocks into small particles and 0.5 to $2 \mathrm{~mm}$ flakes will result due to differential expansion and deaeration from the rapid wetting caused by rising water levels, wave run-up, precipitation or the surge caused by a passing ship. An experiment showed that deaeration becomes a dominant process when the water content of a rewetted sample is lower than 30 to $35 \%$ before rewetting. Therefore, upon rewetting, the desiccated clay is very susceptible to erosion by rain, overland flow, current or wave action. Figure 10 illustrates the disintegration of a desiccated clay sample when immersed in water. When rewetting is due to changing water levels it is, therefore, their fluctuation and frequency of fluctuation rather than their absolute magnitude that results in significant erosion. Also, once the clay banks have been weathered, even the low velocities 
Gaskin, S.J., Pieterse, J. AlShafie, A. \& Lepage, S. (2003) Erosion of undisturbed clay samples from the banks of the St.

Lawrence River, Canadian Journal of Civil Engineering, 30: 585-595. doi: 10.1139/L03-008

found at the banks of the St. Lawrence River will erode the weathered clay until clay of a higher moisture content and lower erosivity is reached.

Vegetation has a number of influences on the erosion of the banks. Figure 11 shows a bank on Iles de Verchères with typical early summer vegetation and the results of erosion of a mature tree. The root matrix of vegetation increases the number of small cracks in the clay, and water uptake by plants will lower the moisture content of the clay, both of which will increase erosion. The canopy will reduce the flow velocities at the water/clay interface when submerged. The canopy and plant mulch will shade the clay above the water line reducing drying. The net effect of these influences is usually reduced erosion. Therefore loss of vegetative cover is likely to have contributed to increased erosion along the banks of the St. Lawrence River. In addition, experiments were performed that show that the presence of roots in the clay matrix increases the breakdown of this type of material when air temperature changes cause cyclic freezing and thawing of the moist bank. This suggests that unlike the summer period, the presence of vegetation in late winter - early spring may increase erosion of the bank.

\section{Conclusions}

Undisturbed samples of the Champlain Sea clay (Leda clay) from the banks of the Iles de Verchères in the St. Lawrence River, where erosion rates of 1 to $3 \mathrm{~m} / \mathrm{yr}$ have been observed, were tested in the laboratory under a unidirectional current and a constant wave climate to investigate erosion mechanisms and factors affecting erosion rates. Waves were the dominant eroding agent. Mass erosion was the most significant erosion process and was determined by the natural structure of the clay. Erosion occurred as larger blocks of material, delineated by cracks 
Gaskin, S.J., Pieterse, J. AlShafie, A. \& Lepage, S. (2003) Erosion of undisturbed clay samples from the banks of the St.

Lawrence River, Canadian Journal of Civil Engineering, 30: 585-595. doi: 10.1139/L03-008

and fissures defined by the planes of weakness in the clay, were dislodged and removed. The planes of weakness were a characteristic of the natural structure of the clay, and were both the point of initiation of erosion and cause of mass erosion. Desiccation followed by rapid rewetting, equivalent to weathering, had the most significant impact on erosion rates, with rates increasing by several orders of magnitude. Moisture loss caused tension cracking of the clay, and upon rapid rewetting it disintegrated into small easily erodible flakes. The presence of a root matrix slowed erosion rates somewhat. Erosion rates increased with steeper bank slopes.

These results can be related to the field conditions for the banks of the St. Lawrence River between Montreal and Lac St. Pierre, as follows:

1. The banks of the river consist of Champlain Sea clay with its natural structure of cracks and fissures which leads to rapid erosion.

2. Waves are the dominant eroding agent.

3. Waves due to ship wakes (surges) have a higher erosive power than wind waves on the unprotected shores close to the navigational channel.

4. Desiccation followed by rapid rewetting results in very high erosion rates.

5. Weathering of the clay banks, due to cyclic wetting and drying, greatly reduces the resistance to erosion.

6. The current velocities at the banks are too low to cause much erosion.

7. Removal of vegetation from the banks will reduce the resistance to erosion. 


\section{Acknowledgements}

The authors would like to acknowledge the support of the Centre Saint-Laurent in collection of the samples.

\section{References}

Argus Groupe-conseil. 1991. L'érosion des îles du Saint-Laurent, tronçon Montréal-Lac Saint-

Pierre. Rapport présenté à Environnement Canada, Service canadien de la Faune et Centre

Saint-Laurent, et Transport Canada, Garde côtière canadienne. 63 p.

Ariathurai, R. \& Arulanandan, K. (1978) Erosion rates of cohesive soils, Journal of the Hydraulics Division, ASCE, 104, HY2: 279-283.

Bishop, C., Skafel, M. \& Nairn, R. (1992) Cohesive profile erosion by waves, In: Coastal Engineering 1992, Proceedings of the $23^{\text {rd }}$ International Conference, Venice, 2976-2989.

Chapuis, R.P. (1986) Quantitative measurement of the scour resistance of natural solid clays, Canadian Geotechnical Journal, 23: 132-141.

Coops, H., Geilen, N., Verheij, H.J., Boeters, R. \& van der Velde, G. (1996) Interactions between waves, bank erosion and emergent vegetation: an experimental study in a wave tank, Aquatic Botany, 53: 187-198.

D’Agnolo, F. (1978) Étude d'érosion; partie du fleuve St. Laurent entre Montréal et Sorel, Garde Côtière Canadienne, Ministère des Transports, 23 p.

Dauphin, D. (2000) Influence de la navigation commerciale et de la navigation de plaisance sur l'érosion des rives du Saint-Laurent dans le tronçon Cornwall - Montmagny. Rapport final. Ministère des Transports du Québec, Service du transport maritime, 103 p. + cartes et annexes. 
Gaskin, S.J., Pieterse, J. AlShafie, A. \& Lepage, S. (2003) Erosion of undisturbed clay samples from the banks of the St.

Lawrence River, Canadian Journal of Civil Engineering, 30: 585-595. doi: 10.1139/L03-008

Govers, G. \& Loch, R.J. (1993) Effects of initial water content and soil mechanical strength on the runoff erosion resistance of clay soils, Australian Journal of Soil Research, 31: 549-566.

Hooke, J.M. (1979) An analysis of the processes or river bank erosion, Journal of Hydrology, 42: $39-62$.

Kamphuis, J.W. (1983) On the erosion of consolidated clay material by a fluid containing sand, Canadian Journal of Civil Engineering, 10, 2: 213-231.

Kamphuis, J.W. (1987) Recession rate of glacial till bluffs, Journal of Waterways, Port, Coastal and Ocean Engineering, ASCE, 113(1):60-73.

Kamphuis, J.W., Gaskin, P.N. \& Hoogendoorn, E. (1990) Erosion tests on four intact Ontario clays, Canadian Geotechnical Journal, 27, 5: 692-696.

Krone, R.B. (1999) Effects of bed structure on erosion of cohesive sediments, Journal of Hydraulic Engineering, 125,12: 1297-1301.

Kuijper, C., Cornelisse, J.M. \& Winterwerp, J.C. (1989) Research on erosive properties of cohesive sediments, Journal of Geophysical Research, 94, C10: 14341-14350.

Lawler, D.M. (1992) Process dominance in bank erosion systems, In: P.A. Carling \& G.E. Petts (eds) Lowland floodplain rivers: Geomorphological perspectives, Wiley, 117-143.

Le Bissonnais, Y., Bruand, A. \& Jamagne, M. (1989) Laboratory experimental study of soil crusting: relation between aggregate breakdown mechanisms and crust structure, Catena, 16: 377-392.

Lefebvre, G. Rohan, K. (1986) On the principal factors controlling erosivity of undisturbed clay, In: Symposium on cohesive shores, Burlington, Ontario, 170-195.

Lefebvre, G., Rohan, K. \& Douville, S. (1985) Erosivity of natural intact structured clay: evaluation, Canadian Geotechnical Journal, 22: 508-517. 
Gaskin, S.J., Pieterse, J. AlShafie, A. \& Lepage, S. (2003) Erosion of undisturbed clay samples from the banks of the St.

Lawrence River, Canadian Journal of Civil Engineering, 30: 585-595. doi: 10.1139/L03-008

Lefebvre, G., Rohan, K. \& Millette, J-P. (1986) Erosivity of intact clay: influence of the natural structure, Canadian Geotechnical Journal, 23: 427-434.

Lehoux, D. 1996. Restauration naturelle des rives du Saint-Laurent entre Cornwall et l'Île d'Orléans. Guide d'intervention +4 documents cartographiques. Environment Canada, Canada Wildlife Service, Quebec Ministry of Transport, James Bay Energy Society, Ducks Unlimited and Les Consuiltants en environnement Argus. Multiple pagination.

Lepage, S. and Richard, L.-F. (2001) Utilisation d'une nouvelle structure benthique pour l'étude de l'érosion et de la remise en suspension des sédiments en milieu littoral peu profond. Proceedings of the Canadian Coastal Conference. Quebec, May 16-19 2001. Bernard F. Long, ed. pp. 493-506.

Lepage, S., Rondeau, B., Richard, L-F., Gaskin, S., Al Shafie, A., Pieterse, J., Bouchard M. and Lafleur, Y. (2001) Erosion of post-glacial marine clays in the Varennes-Contrecoeur reach of the St. Lawrence River : the influence of hydro-meteorological cycles and anthropogenic activities. $7^{\text {th }}$ International Conference on Fluvial Sedimentology. Lincoln, Nebraska, 6-10 August 2001.

Maa, P.Y. \& Mehta, A.J. (1987) Mud erosion by waves: a laboratory study, Continental Shelf Research, 7, 11/12: 1269-1284.

Mehta, A.J. (1991) Review notes on cohesive sediment erosion, In: Proceedings of the Speciality conference on quantitative approaches - Coastal Sediments 1991, 40-53.

Ouellet, Y. \& Baird, W. (1978) L'erosion des rives dans le Saint-Laurent, Canadian Journal of Civil Engineering, 5: 311-323.

Panabokke, C.R. \& Quirk, J.P. (1957) Effect of initial water content on stability of soil aggregates in water, Soil Science, 83: 185-195. 
Gaskin, S.J., Pieterse, J. AlShafie, A. \& Lepage, S. (2003) Erosion of undisturbed clay samples from the banks of the St.

Lawrence River, Canadian Journal of Civil Engineering, 30: 585-595. doi: 10.1139/L03-008

Panasuk, S. (1987) L'érosion actuelle et récente des Iles de Varennes dans la région de

Montréal, rapport de recherche pour la maitrise en science de l'environnement, Université du Québec a Montréal, Québec, Canada.

Partheniades, E. (1965) Erosion and deposition of cohesive soils, Journal of the Hydraulics Division, ASCE, 91, HY1: 105-139.

Rohan, K., Lefebvre, G. \& Douville, S. (1980) Mécanismes d'érosion de l'argile intacte, In: Proceedings of the Canadian Coastal Conference 1980, National Research Council Canada, 200-219.

Rondeau, B., Cossa, D., Gagnon, P. and Bilodeau, L. (2000) Budget and sources of suspended sediments in the St. Lawrence River, Hydrol. Process. 14: 21-36.

Samad, M., Baird, D.C., Vermeyen, T.B. \& Melford, B.W. (1995) Erosion characteristics of cohesive sediments, In: Proceedings of the International Water Resources Conference, 1: 425-429.

Sangrey, D. A. (1972) Naturally cemented sensitive soils, Geotechnique 22, No. 1, pp. 139-152.

Skafel, M. (1995) Laboratory measurement of nearshore velocities and erosion of cohesive sediment (till) shoreline, Coastal Engineering, 24, 3: 343-349.

Skafel, M. \& Bishop, C. (1994) Flume experiments on the erosion of till shores by waves, Coastal Engineering, 23: 329-348.

Thorne, C.R. (1990) Effects of vegetation on riverbank erosion and stability, In: J.B. Thornes (editor) Vegetation and Erosion. Processes and Environments, Wiley, Chichester, 125-144.

Truman, C.C., Bradford, J.M. \& Ferris, J.E. (1990) Antecedent water content and rainfall energy influence on soil aggregate breakdown, Soil Science Society of America Journal, 54: 13851392. 
Author accepted version. Final publication as:

Gaskin, S.J., Pieterse, J. AlShafie, A. \& Lepage, S. (2003) Erosion of undisturbed clay samples from the banks of the St.

Lawrence River, Canadian Journal of Civil Engineering, 30: 585-595. doi: 10.1139/L03-008

USACE - US Army Corps of Engineers (1984) Shore Protection Manual, US Government

Printing Office, Washington, D.C., USA.

Vallejo, L.E. (1980) Analysis of wave-induced erosion of cohesive soils forming coastal bluffs, In: Proceedings of the Canadian Coastal Conference 1980, National Research Council

Canada, 220-228.

Zreik, D.A., Krishnappan, B.G., Germain, J.T., Madsen, O.S. \& Ladd, C.C. (1998) Erosional and mechanical strengths of deposited cohesive sediment, Journal of Hydraulic Engineering, 124, 11:1076-1085.

\section{List of symbols}
$k_{s}$ roughness height
$K \quad$ von Karman's constant, 0.4
$u \quad$ velocity of flow at depth $\mathrm{z}$
$U^{*} \quad$ bed shear velocity
$v$ kinematic viscosity of water
$\rho$ density of water
$\tau_{c r} \quad$ critical shear stress 
Author accepted version. Final publication as:

Gaskin, S.J., Pieterse, J. AlShafie, A. \& Lepage, S. (2003) Erosion of undisturbed clay samples from the banks of the St. Lawrence River, Canadian Journal of Civil Engineering, 30: 585-595. doi: 10.1139/L03-008

Table 1. Erosion tests on undisturbed samples, critical shear stress.

\begin{tabular}{|c|c|c|c|}
\hline Study & Material & $\begin{array}{l}\text { Erosion test } \\
\text { method }\end{array}$ & $\begin{array}{l}\text { Critical shear stress } \\
\text { Pa }\end{array}$ \\
\hline Rohan et al. (1980) & $\begin{array}{l}2 \text { unweathered, sensitive, } \\
\text { structured marine clays from } \\
\text { Eastern Canada }\end{array}$ & flume test & $\begin{array}{c}\text { Low erosion at } \\
\text { applied shear stress of } \\
7.5\end{array}$ \\
\hline $\begin{array}{l}\text { Lefebvre et al. } \\
(1985) \\
(1986)\end{array}$ & $\begin{array}{l}\text { unweathered brittle } \\
\text { structured marine clays from } \\
\text { Eastern Canada: }\end{array}$ & drill hole test & \\
\hline & 3 Champlain Sea clays & & $>350->450$ \\
\hline & 1 Tyrell Sea clay. & & $100-200$ \\
\hline Chapuis (1986) & 2 Northern Quebec clays & rotating & \\
\hline & & cylinder test & $4-9$ \\
\hline $\begin{array}{l}\text { Kamphuis et al. } \\
(1990)\end{array}$ & $\begin{array}{l}1 \text { Glaciolacustrine silty clay, } \\
3 \text { silty clays from Ontario }\end{array}$ & flume test & $\begin{array}{c}0.5-2 \\
0-6\end{array}$ \\
\hline Bishop et al. (1992) & $\begin{array}{l}1 \text { Port Stanley Till (shore } \\
\text { Lake Erie) }\end{array}$ & flume test & 7 \\
\hline
\end{tabular}


Author accepted version. Final publication as:

Gaskin, S.J., Pieterse, J. AlShafie, A. \& Lepage, S. (2003) Erosion of undisturbed clay samples from the banks of the St.

Lawrence River, Canadian Journal of Civil Engineering, 30: 585-595. doi: 10.1139/L03-008

Table 2. Summary of samples subjected to a unidirectional current.

\begin{tabular}{|c|c|c|c|c|}
\hline Sample description & $\begin{array}{c}\text { Velocity } \\
\text { range tested } \\
\mathrm{m} / \mathrm{s}\end{array}$ & $\begin{array}{c}\text { Erosion } \\
\text { period } \\
\text { hrs }\end{array}$ & $\begin{array}{c}\text { Critical } \\
\text { velocity } \\
\mathrm{m} / \mathrm{s}\end{array}$ & $\begin{array}{c}\text { Estimated } \\
\text { critical shear } \\
\text { stress }^{a} \\
\mathrm{~Pa} \\
\end{array}$ \\
\hline 1: Natural moisture content, no roots & $1.57-1.76$ & 12 & 1.6 & $10-20$ \\
\hline 2: Natural moisture content, no roots & $0.17-1.11$ & 18 & 1.1 & $6-9$ \\
\hline $\begin{array}{l}\text { 3: Pre-soaked, natural moisture } \\
\text { content, with roots }\end{array}$ & $1.05-1.21$ & 31 & 1.1 & $6-9$ \\
\hline $\begin{array}{l}\text { 4: Sample } 3 \text { air dried } 3 \text { days, with } \\
\text { roots }\end{array}$ & 1.05 & 0.5 & $<<1$ & $<<5$ \\
\hline $\begin{array}{l}\text { 5: Pre-soaked, natural moisture } \\
\text { content, with roots }\end{array}$ & $1.05-1.25$ & 70 & 1.2 & $7-11$ \\
\hline $\begin{array}{l}\text { 6: Pre-soaked, natural moisture } \\
\text { content, no roots, } 2 \text { layers }{ }^{b}\end{array}$ & $1.05-1.16$ & 40 & 1.1 & $6-9$ \\
\hline
\end{tabular}

${ }^{a}$ shear stress estimated by assuming a logarithmic velocity profile of rough turbulent flow to calculate shear velocity and hence shear stress

${ }^{b}$ a layer of inorganic clay of high plasticity with $15 \%$ sand overlying the clay 
Gaskin, S.J., Pieterse, J. AlShafie, A. \& Lepage, S. (2003) Erosion of undisturbed clay samples from the banks of the St.

Lawrence River, Canadian Journal of Civil Engineering, 30: 585-595. doi: 10.1139/L03-008

Table 3. Summary of erosion rates for samples subjected to a constant wave climate.

\begin{tabular}{|c|c|c|c|c|}
\hline Sample description & $\begin{array}{l}\text { Erosion } \\
\text { period } \\
\text { hrs }\end{array}$ & $\begin{array}{l}\text { Eroded } \\
\text { volume } \\
\text { liters }\end{array}$ & $\begin{array}{l}\text { Rate of } \\
\text { erosion } \\
\mathrm{ml} / \mathrm{hr}\end{array}$ & $\begin{array}{l}\text { Size of } \\
\text { largest } \\
\text { particles }^{a} \\
\text { mm }\end{array}$ \\
\hline 1: Natural moisture content, no roots, slope of 0.18 & 168 & 1.0 & 6 & 27 \\
\hline $\begin{array}{l}\text { 2: Natural moisture content, with roots, slope of } \\
0.18\end{array}$ & 336 & 0.2 & 0.6 & 20 \\
\hline $\begin{array}{l}\text { 3: Natural moisture content, pre-soaked }{ }^{b} \text {, with } \\
\text { roots, slope of } 0.18\end{array}$ & 336 & 1.1 & 3 & 44 \\
\hline $\begin{array}{l}\text { 4: Natural moisture content, no roots, slope of } \\
0.0182 \text { layer sample - clay/mix of sand and } \\
\text { clay }\end{array}$ & 2 & $5.0^{c}$ & 2500 & $\sim 40$ \\
\hline $\begin{array}{l}\text { 5: Natural moisture content, pre-soaked }{ }^{d}, \text { no roots, } \\
\text { slope of } 0.18\end{array}$ & 168 & 1.35 & 8 & 52 \\
\hline 6: Natural moisture content, no roots, slope of 0.36 & 168 & 2.0 & 12 & 55 \\
\hline 7: Air dried for 3 weeks, no roots, slope of 0.18 & 2 & $\begin{array}{l}18 \\
\text { (complete } \\
\text { sample) }\end{array}$ & $>9000$ & $1-2$ \\
\hline $\begin{array}{l}\text { 8: Sample } 3 \text { air dried for } 2 \text { weeks, with roots, slope } \\
\text { of } 0.18\end{array}$ & 2 & $\begin{array}{l}18 \\
\text { (complete } \\
\text { sample) }\end{array}$ & $>9000$ & $1-2$ \\
\hline $\begin{array}{l}\text { 9: Sample } 2 \text { air dried for } 2 \text { weeks, with roots, slope } \\
\text { of } 0.18\end{array}$ & 2 & $\begin{array}{l}18 \\
\text { (complete } \\
\text { sample) }\end{array}$ & $>9000$ & $1-2$ \\
\hline $\begin{array}{l}\text { 10: Sample } 5 \text { air dried for } 2 \text { weeks, no roots, slope } \\
\text { of } 0.18\end{array}$ & 2 & $\begin{array}{l}18 \\
\text { (complete } \\
\text { sample) }\end{array}$ & $>9000$ & $1-2$ \\
\hline
\end{tabular}

${ }^{a}$ average size of largest particles

${ }^{b}$ pre-soaked for 2 weeks, vertical swelling of $2 \mathrm{~mm}$

${ }^{c}$ eroded volume was layer of sand and clay mixture

${ }^{d}$ pre-soaked for 1 week, no swelling 
Author accepted version. Final publication as:

Gaskin, S.J., Pieterse, J. AlShafie, A. \& Lepage, S. (2003) Erosion of undisturbed clay samples from the banks of the St.

Lawrence River, Canadian Journal of Civil Engineering, 30: 585-595. doi: 10.1139/L03-008

\section{Figures}

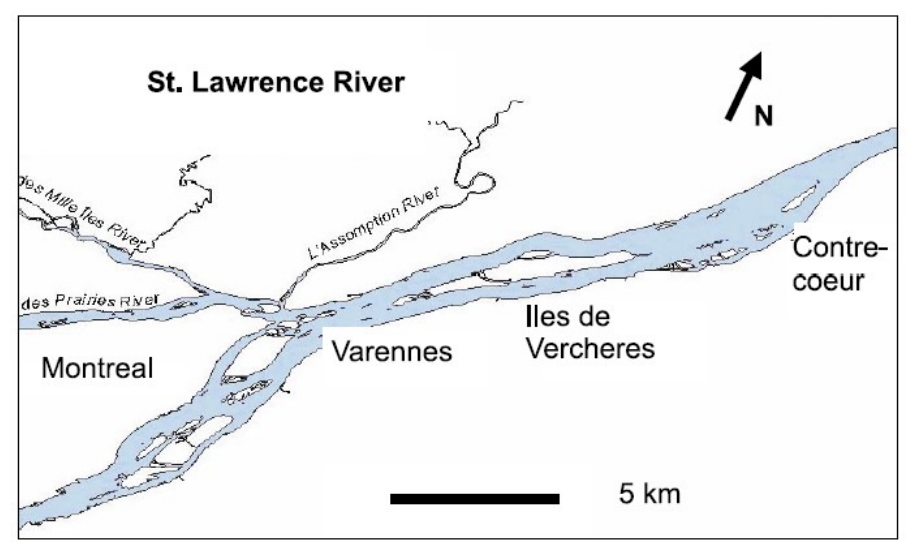

Figure 1. Map of study area at Verchères in the Montreal to Contrecoeur reach of the St.

\section{Lawrence River.}

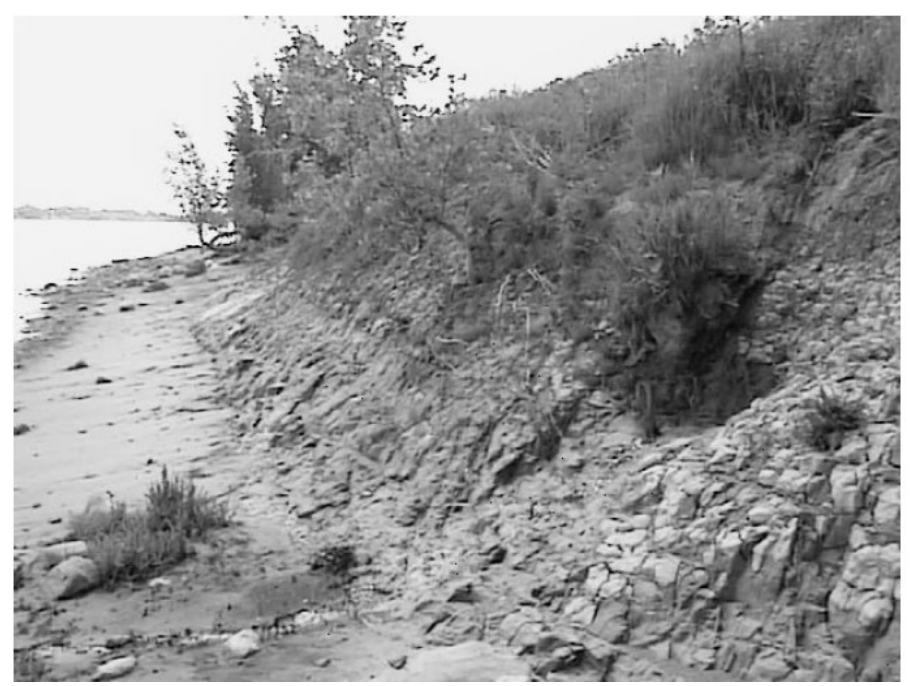

Figure 2. Typical eroding clay bank on the south shore of Iles de Verchères. 
Author accepted version. Final publication as:

Gaskin, S.J., Pieterse, J. AlShafie, A. \& Lepage, S. (2003) Erosion of undisturbed clay samples from the banks of the St.

Lawrence River, Canadian Journal of Civil Engineering, 30: 585-595. doi: 10.1139/L03-008

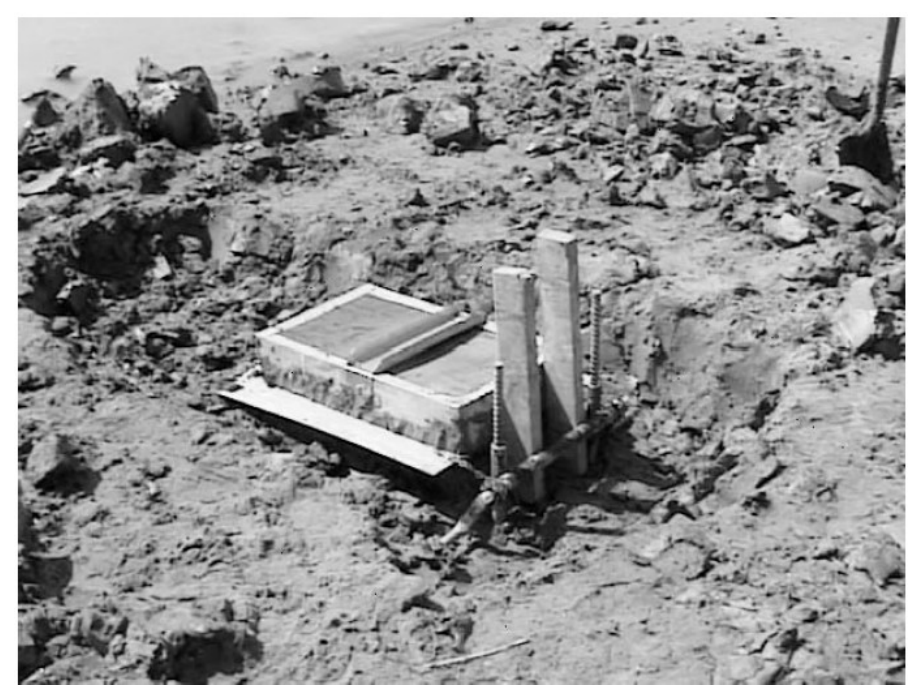

Figure 3. Method for obtaining undisturbed clay samples.

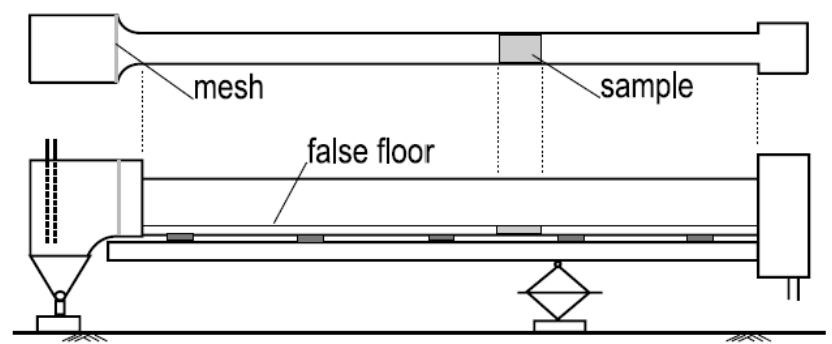

Figure 4. Tilting flume for tests of erosion due to a unidirectional current.

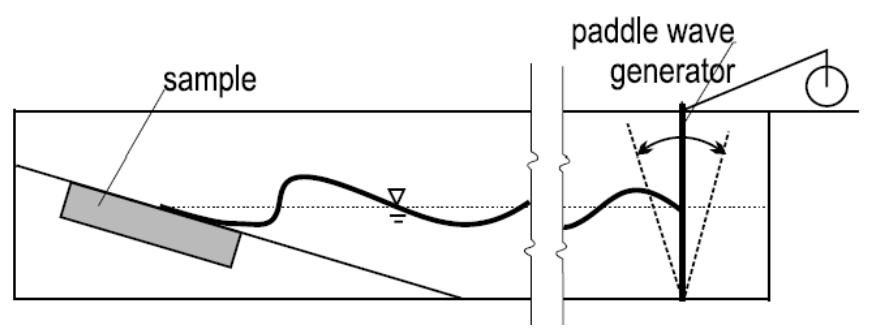

Figure 5. Wave tank for tests of erosion due to a constant wave climate. 
Author accepted version. Final publication as:

Gaskin, S.J., Pieterse, J. AlShafie, A. \& Lepage, S. (2003) Erosion of undisturbed clay samples from the banks of the St.

Lawrence River, Canadian Journal of Civil Engineering, 30: 585-595. doi: 10.1139/L03-008
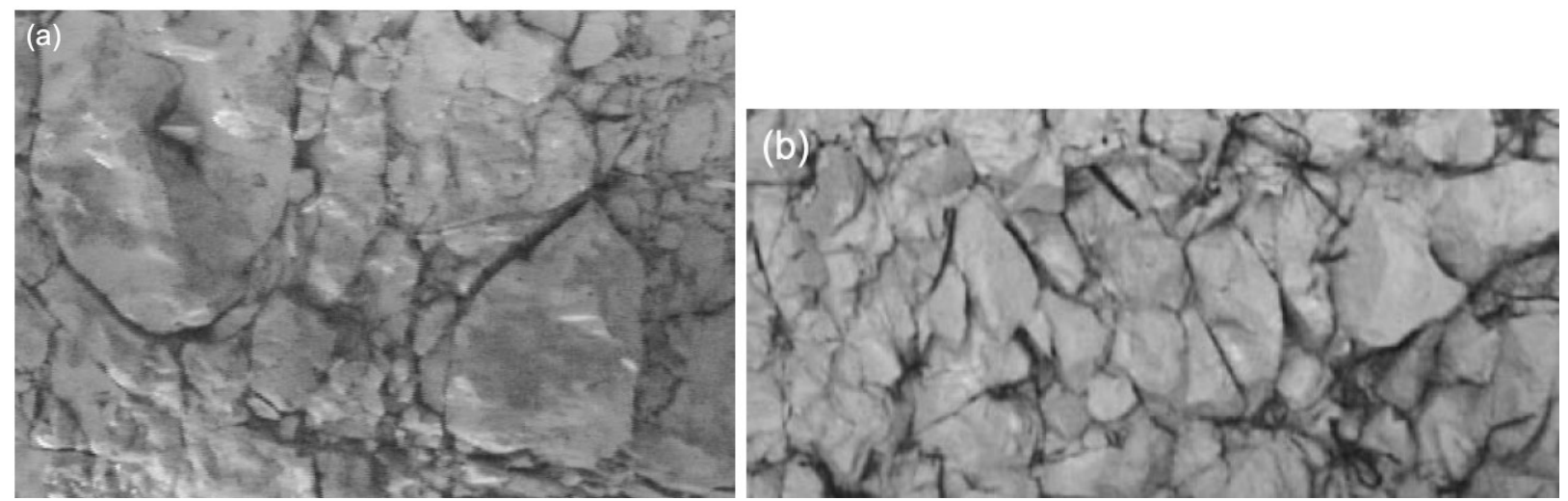

Figure 6. Typical test sample after erosion, a) due to a unidirectional current and b) due to waves.
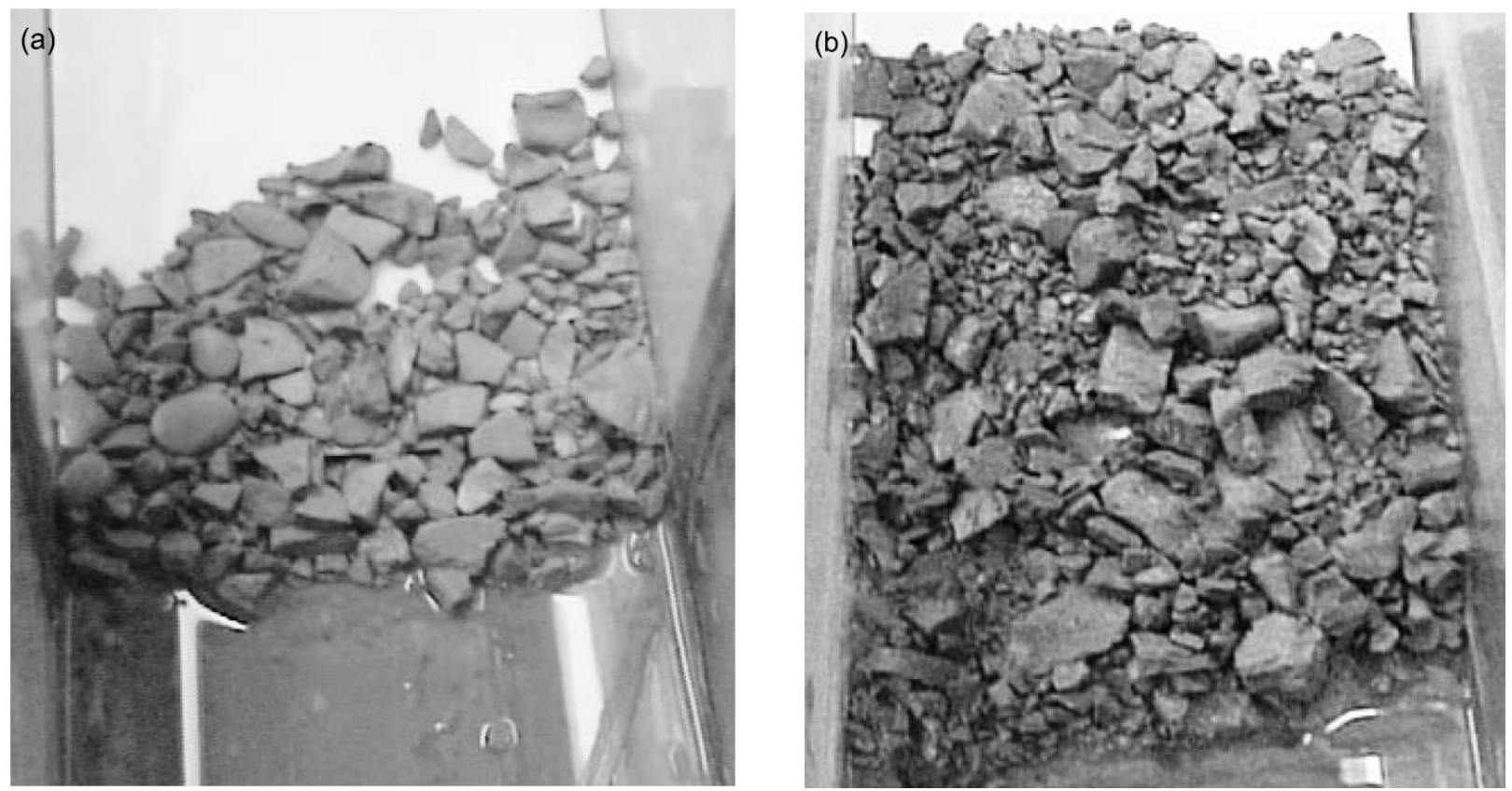

Figure 7. Blocks of clay removed by waves as a result of the mass erosion process, a) slope of $0.18\left(10^{\circ}\right)$ and $\left.b\right)$ slope of $0.36\left(20^{\circ}\right)$. 
Author accepted version. Final publication as:

Gaskin, S.J., Pieterse, J. AlShafie, A. \& Lepage, S. (2003) Erosion of undisturbed clay samples from the banks of the St.

Lawrence River, Canadian Journal of Civil Engineering, 30: 585-595. doi: 10.1139/L03-008

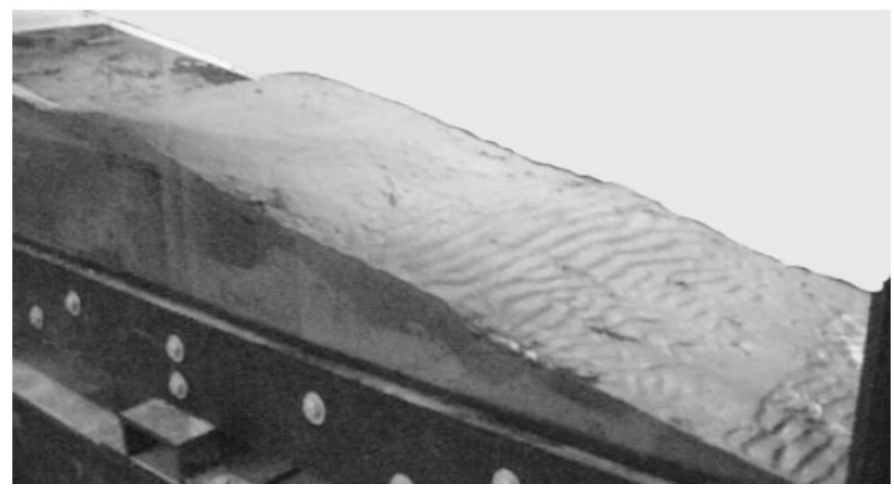

Figure 8. Erosion due to waves of a sample with low initial moisture content due to desiccation.
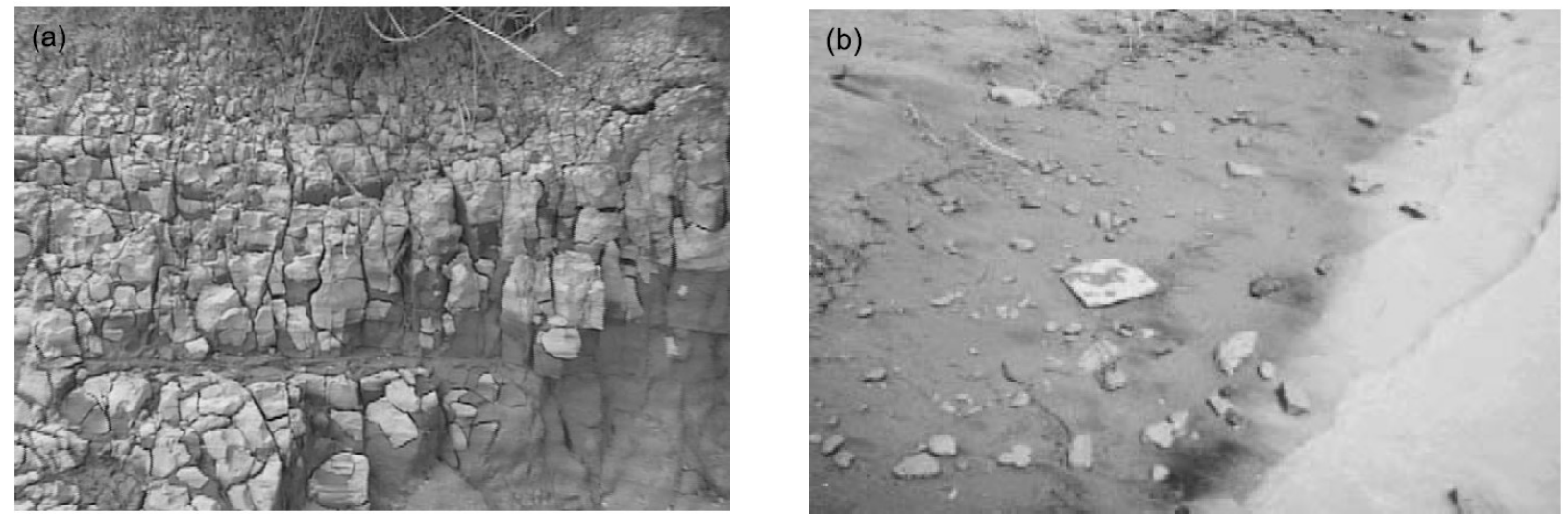

Figure 9. a) Typical bank exhibiting desiccation, b) clay "stones" resulting from erosion of bank.
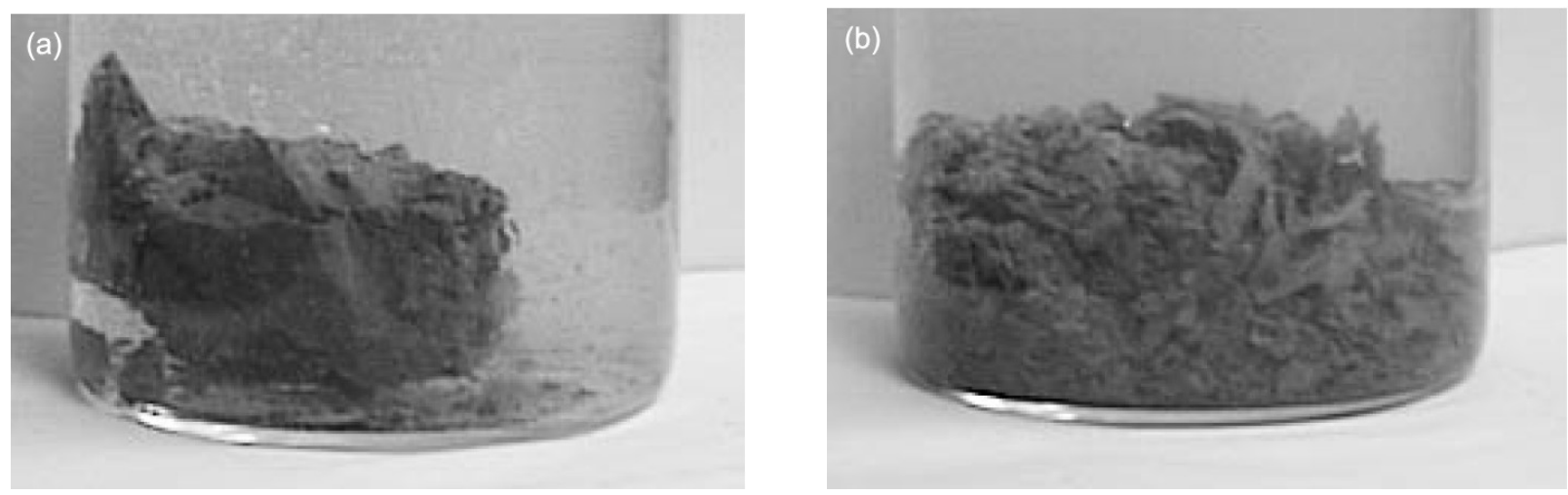

Figure 10. Disintegration of desiccated clay sample upon rewetting, a) at $\mathrm{t}=0$ mins and $\mathrm{b}$ ) at $\mathrm{t}=$ 5 mins. 
Author accepted version. Final publication as:

Gaskin, S.J., Pieterse, J. AlShafie, A. \& Lepage, S. (2003) Erosion of undisturbed clay samples from the banks of the St.

Lawrence River, Canadian Journal of Civil Engineering, 30: 585-595. doi: 10.1139/L03-008

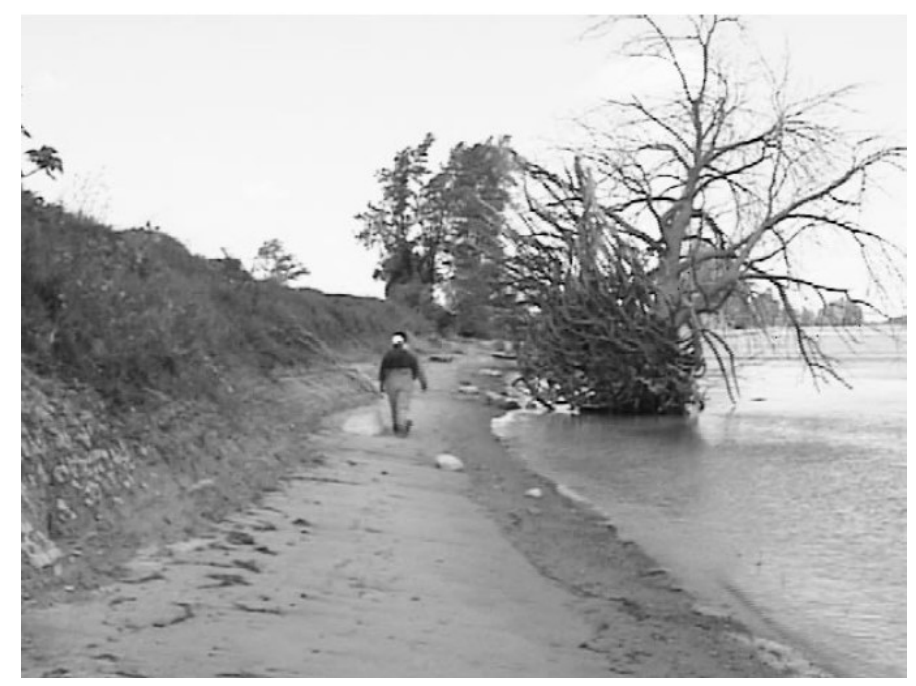

Figure 11. Vegetation on the river banks showing erosion. 